Regular Research Article

\title{
Managing Forest Conflicts: Perspectives of Indonesia's Forest Management Unit Directors
}

\author{
Larry A. Fisher ${ }^{1, *}$, , Yeon-Su Kim ${ }^{2}$, Sitti Latifah ${ }^{3}$, Madani Makarom ${ }^{4}$ \\ 1 School of Natural Resources and the Environment, University of Arizona, Tucson, AZ 85721, USA; \\ lafisher@email.arizona.edu \\ 2 School of Forestry, Northern Arizona University, Flagstaff, AZ 86011, USA. e-mail: ysk@nau.edu \\ 3 Foretsry Study Program, University of Mataram, Indonesia; e-mail: sittilatifah@gmail.com \\ 4 West Rinjani Forest Management Unit, Lombok, Indonesia; e-mail: aganampuh@gmail.com \\ * Correspondence author: lafisher@email.arizona.edu
}

\begin{abstract}
Recent expansion of the forestry and plantation sectors in Indonesia has intensified agrarian and natural resource conflicts, and created increased awareness of the social, economic and environmental impacts of these disputes. Addressing these disputes is a critical issue in advancing Indonesia's commitment to sustainable forest management. The Forest Management Units (Kesatuan Pengelolaan Hutan, or KPH), have become the pivotal structural element for managing all state forests at the local level, with responsibility for conventional forest management and policy implementation (establishing management boundaries, conducting forest inventory, and developing forest management plans), as well as the legal mandate to communicate and work with indigenous people and local communities. This paper presents the results of a national survey of all currently functioning KPH units, the first of its kind ever conducted with $\mathrm{KPH}$ leadership, to obtain a system-wide perspective of the KPHs' role, mandate, and capacity for serving as effective intermediaries in managing forest conflicts in Indonesia. The survey results show that the KPHs are still in a very initial stage of development, and are struggling with a complex and rapidly evolving policy and institutional framework. The most common conflicts noted by respondents included forest encroachment, tenure disputes, boundary conflicts, and illegal logging and land clearing. $\mathrm{KPH}$ leadership views conflict resolution as among their primary duties and functions, and underscored the importance of more proactive and collaborative approaches for addressing conflict, many seeing themselves as capable facilitators and mediators. Overall, these results juxtapose a generally constructive view by KPH leadership over their role and responsibility in addressing forest management conflicts, with an extremely challenging social, institutional, and political setting. The KPHs can certainly play an important role as local intermediaries, and in some cases, as facilitative mediators in resolving local conflicts, but only with a more concerted effort from central and provincial government authorities to provide greater consistency in policies and regulations, improved policy communication, and a sustained commitment to strengthening the capacity of individual $\mathrm{KPHs}$.
\end{abstract}

Keywords: Sustainable forest management; conflict resolution; Indonesia

\section{Introduction}

Conflicts over the management of natural resources are common phenomena everywhere in the world (Ayling and Kelly, 1997; Hellstrom, 2001; Yasmi et al., 2006; Gritten and Mola-Yudego, 2011). This has been well documented in the forestry sector, where national and regional government priorities clash over jurisdictional control, and compete with local communities over their livelihood needs (De Koning et al., 2008; Harwell, 2011; Yasmi et al., 2012). More recently, localized forest management conflicts have increasingly become nested within the broader national and international debates over timber extraction, harvesting of valuable non-timber forest products, rapid land conversion to palm oil and pulp and paper plantations, biodiversity conservation, and global carbon sequestration (Yasmi et al., 2012; Dhiaulhaq et al., 2015). 
Various authors have discussed the complexity of natural resource management conflicts, and have developed various typologies, using actors, causes, intensity, tractability, sources of power, and management strategies (FAO, 2000; Gritten and Mola-Yudego, 2011; Krott et al., 2014). When managed effectively, these conflicts can serve as constructive forces, driving social change for continuous evolution of society (Lee, 1997; Deloges and Gauthier, 1997; Castro and Nielsen, 2001; Hellstrom, 2001). However, in many cases, conflicts escalate into damaging situations with substantial social and economic costs, including the disenfranchisement of local communities, social protests, and the engagement of security forces and the use of lethal violence (Bannon and Collier, 2003). For the private sector, these conflicts can represent significant financial costs and risks; in an analysis of projects in the extractive sector, researchers reported losses of roughly US\$20 million per week in individual project settings, largely due to lost productivity and sales (Davis and Franks, 2014).

The number and intensity of forest and land use conflicts are particularly acute in developing countries blessed with rich natural resources and cultural diversity, but plagued with weak governance systems and economic pressures for resource exploitation (de Koning et al., 2008). Indonesia is a prime example of such countries (Gritten and Mola-Yudego, 2011).

The recent expansion of the forestry and plantation sectors in Indonesia has intensified agrarian and natural resource conflicts, especially those related to land tenure, forest boundary and classification, and illegal logging and land clearing, and created increased awareness of the social, economic and environmental impacts of these disputes (Forest Watch Indonesia, 2011; Dhiaulhaq et al., 2014). Persch-Orth and Mwangi (2016) report that Indonesia has the highest number of industrial tree plantation conflicts worldwide. In 2013, the Consortium for Agrarian Reform (Konsorsium Pembaharuan Agraria, or KPA), reported 396 cases of agrarian conflict (affecting more than 1.2 million ha), up from 198 cases $(300,000$ ha) during the previous year. A World Bank study (2014) reported that nearly 25 million ha of all designated state forest lands (or kawasan hutan) are in conflict (more than 20 percent of the total forest area, encompassing nearly 20,000 villages), primarily due to competing land claims and governance issues. The Institute for Policy Analysis of Conflict (IPAC), has underscored the fact that "land and resource conflicts are becoming a major source of lethal violence in Indonesia and there are no good mechanisms for resolving them" (IPAC, 2014).

Indonesia has the third largest tropical forest in the world, with one of the world's fastest rates of deforestation - more than $1,000 \mathrm{~km}^{2} /$ year (Hansen et al., 2013). At the same time, Indonesia has emerged as one of the major beneficiaries of global negotiations to mitigate climate change through improved forest management. Substantial financial gains through international climate mitigation initiatives provide strong motivation for Indonesia to reform its forestry sector (Brockhaus et al., 2012). Indonesia's Forest Management Units (Kesatuan Pengelolaan Hutan, or $\mathrm{KPH})$, have become the pivotal structural element for managing all state forests at the local level (MoF, 2014; Hernowo and Ekawati, 2014). By May, 2012, Indonesia had projected the designation of $600 \mathrm{KPHs}$ nationally, covering an area of 130,680,000 ha, with multiple KPHs established in each District, and oversight and management primarily at the provincial level. ${ }^{1}$ Each $\mathrm{KPH}$ is expected to carry out conventional tasks for forest management, such as establishing its management boundaries, conducting forest inventory, and developing forest management plans (ROI, 2007). The KPHs also implement various forest management activities at the site level, including the application of national, provincial and district forest policies (MOF, 2014). In addition, the KPHs have become the first government entity managing natural resources with a legal mandate to communicate and work with indigenous people and local communities (Kartodihardjo et al., 2011; Bae et al., 2014).

\footnotetext{
${ }^{1}$ See: http://www.forclime.org/documents/Brochure/Bahasa/FAQ\%20KPH\%20_Bahasa.pdf

2 Partnership agreements (kemitraan) are a relatively recent program initiative from the Minister of Forestry (Ministerial Regulation No P.39/2013) that augments existing community-based forestry initiatives such as village forests (hutan desa), social forestry (hutan kemasyarakatan, or HKM), and Partnership agreements
} 
Although the central government created the KPH system, jurisdiction over its operation is now vested with the provincial government where the KPH is located (Sahide et al., 2016a,b). As an emerging institutional actor bridging multiple jurisdictions and stakeholders within the forestry sector, they are explicitly viewed as a potential mediator in systematically addressing forest management disputes. Individual KPHs are expected to make sense of policies and regulations from different levels of governments, manage ambiguity, and negotiate, bargain and exercise discretion in implementing these policies within local contexts (Kim et al., 2015).

Given these expectations for the KPHs' role in managing forest conflicts in Indonesia, it is important to understand $\mathrm{KPH}$ perspectives of both their mandate and capacity for managing these conflicts. This paper presents the results of a national survey, the first of its kind ever conducted with KPH leadership, to obtain a system-wide perspective of all KPH units by eliciting KPH directors' perspectives on their role, mandate, and capacity for serving as effective intermediaries in managing forest conflicts in Indonesia.

\section{Methods}

The research team developed an initial draft questionnaire with primary input from selected $\mathrm{KPH}$ directors (kepala) and national experts in the forestry sector. Discussions with several KPH leaders reinforced their interest in gaining a national perspective on the nature of forest management conflicts, and on KPH attitudes, capability, responses, and priorities. The survey instrument was further refined after preliminary testing with a smaller group of resource persons (see Acknowledgments). Revisions included editing of the questions' phrasing and vocabulary for more ready understanding, and adjustment of some of the question formats. The survey was formatted and distributed in Bahasa Indonesia using the on-line service Survey Monkey (www.surveymonkey.com). Initial discussions with $\mathrm{KPH}$ directors suggested that the use of an on-line survey was practicable, given general email accessibility, and their strong interest in pioneering the use of this rapid response tool.

The survey was distributed via email link in June 2016 to all KPH directors, through the email mailing list of the National Association of KPHs (the professional organization representing all KPHs in Indonesia). The email included an introductory message (also in Bahasa Indonesia) from the national coordinator explaining the purpose, importance, and need for participating in the survey. Three subsequent reminders were sent to increase the survey response rate.

Invitations to participate in the survey were sent to $125 \mathrm{KPH}$ directors, as identified by the Association's most current membership and email distribution list (note that the time of the survey, $130 \mathrm{KPHs}$ had been officially designated as operational). The introductory email asked specifically that the KPH directors personally fill out the surveys, in order to obtain direct responses from the highest level of KPH leadership. However, survey respondents were allowed to remain anonymous, to encourage candid participation, without concern that responses would be traced back to individuals.

The survey consisted of 19 questions, covering the following topics:

- General information about the KPH (location, area, status, staffing)

- Respondents' personal information (age, years of service, educational background)

- Perspectives about KPH roles and functions

- Perceptions of conflict (type and extent of conflicts, actions to date, outcomes, needs)

- Roles of other actors (perceived responsibilities, potential contributions)

An English translation of the survey questionnaire is presented in Appendix 1. All survey responses were received during June - July, 2015.

\section{Results}

We received responses from $87 \mathrm{KPHs}$ (69.6\%), although not all respondents filled out every question of the survey. Analysis of results was therefore adjusted for individual questions, accounting for variable response rates. 


\subsection{Overview of KPHS represented in the survey}

Responses were received from all regions, with the majority of responses from three main islands: Sumatera (35.6\%), Sulawesi (20.7\%) and Kalimantan (16.1\%) (see Table 1). These figures are generally representative of the current national distribution of KPHs and their sizes. KPH responses were somewhat evenly distributed in terms of size, with more than half of the KPHs managing less than 100,000 ha.

Table 1. Responses by Location and Size

\begin{tabular}{|c|c|c|c|c|c|c|c|}
\hline & Less than & $50 \mathrm{~K}-100$ & $100 \mathrm{~K}-15$ & $150 \mathrm{~K}-$ & Over & Blank & \\
\hline Location \size & $50 \mathrm{~K}$ ha & $\mathrm{K}$ ha & $0 \mathrm{~K}$ ha & $250 \mathrm{~K}$ ha & $250 \mathrm{~K}$ ha & & Total (\%) \\
\hline Java & 1 & & & & & & $1(1.1)$ \\
\hline Maluku & 1 & & & 1 & & & $2(2.3)$ \\
\hline Papua & & 1 & & 2 & & & $3(3.4)$ \\
\hline \multicolumn{8}{|l|}{ Bali-Nusa } \\
\hline Tenggara & 9 & 3 & & & & & $12(13.8)$ \\
\hline Kalimantan & 2 & 2 & 4 & 1 & 5 & 1 & $14(16.1)$ \\
\hline Sulawesi & 4 & 3 & 6 & 4 & 1 & 2 & $18(20.7)$ \\
\hline Sumatera & 9 & 13 & 4 & 1 & 4 & & $31(35.6)$ \\
\hline Blank & & & & & & 3 & $3(3.4)$ \\
\hline TOTAL (\%) & $26(29.9)$ & $22(25.3)$ & $14(16.1)$ & $9(10.3)$ & $10(11.5)$ & $6(6.9)$ & 87 \\
\hline
\end{tabular}

Since the KPHs have all been established since 2007 (Government Regulation 6/2007), respondents' experience working officially within the $\mathrm{KPH}$ system is relatively recent, with $24.7 \%$ reporting less than one year of working experience, $42.9 \%$ from $1-2$ years, $28.6 \%$ from $3-5$ years, and just 3.9\% with more than five years experience. The number of respondents by age: $6.4 \%$ between $20-30$ years, $35.9 \% 31-40$ years, $34.6 \% 41-50$ years, and $23.1 \%$ between $51-60$ years (no respondents identified as being older than 60 years). Thus it appears that although experience within the $\mathrm{KPH}$ system is rather limited, KPH directors are generally more mature (57.7\% above 41 years), and they do bring considerable professional experience to their more recent work with the $\mathrm{KPHs}$.

$\mathrm{KPH}$ staffing varies significantly in both size and status (see Table 2). Most of the KPHs reported less than 20 civil service staff (35.8\% less than 5, 34.6\% between 6 and 10, and 21.0\% between 11 and 20), with 4.9\% (or $4 \mathrm{KPHs}$ ) between 21 and 50, 2.5\% (2 KPHs) between 51 - 100, with only one $\mathrm{KPH}(1.23 \%)$ reporting more than 100 civil service staff. Given the challenges of managing these extensive units with so few permanent staff, many of the KPHs augment their staffing needs with short-term hires of newly graduated forestry students (Kontrak Bakti Sarjana Rimbawan), and with contract labor hired for specific programs. This may tend to restrict management capacity, professionalism, and continuity within the KPH system, as many of the KPHs tend to rely on short-term and temporary staff. The number of staff, particularly the number of civil servants, does not correlate with the size of KPHs; however, the larger KPHs do tend to rely more on project-based temporary staff. 
Table 2: Average number of staff per unit, by employment status and KPH size

\begin{tabular}{lrrrr}
\hline $\begin{array}{l}\text { Size } \begin{array}{l}\text { KPH } \\
\text { Staff Status }\end{array} \\
\text { Civil Servants }\end{array}$ & Contract (forestry students) & \multicolumn{2}{c}{$\begin{array}{l}\text { Contract } \\
\text {-project } \\
\text { based }\end{array}$} & TOTAL \\
\hline All Size & 12.34 & 9.84 & 9.24 & 31.4 \\
Less than 50K ha & 15.8 & 10.5 & 11.9 & 38.2 \\
50K-100K ha & 12.6 & 8.4 & 5.1 & 26.0 \\
100K-150K ha & 7.6 & 12.0 & 4.4 & 24.0 \\
150K- 250K ha & 9.4 & 9.8 & 5.4 & 24.7 \\
Over 250K ha & 13.9 & 8.7 & 22.3 & 44.8 \\
\hline
\end{tabular}

In terms of educational background, most respondents reported receiving Bachelors' (59.5\%) or Masters' (36.7\%) degrees, with only two respondents $(2.5 \%)$ reporting a high school level education, and one (1.3\%) having completed a doctorate degree. The great majority completed their studies in traditional fields such as forestry (69.7\%) and agriculture (10.5\%), with fewer numbers reporting degrees in law (6.6\%), social sciences (5.3\%), and economics (3.95\%). Once again, it is clear that KPH directors do bring significant education and experience to their work with the $\mathrm{KPH}$, despite their limited experience working within these new management units.

Nevertheless, little more than half the respondents $(55.13 \%)$ reported having participated in any coursework or training related to conflict management, and of these, most $(56.8 \%)$ cited a single introductory training event. These included basic skills training in conflict mapping, conflict management, tenurial conflict, partnership building, and facilitation training. Many cited the basic "Conflict Mapping and Conflict Management" or "Managing Tenurial Conflict" training courses they receive during their introductory in-service training for officials nominated to become $\mathrm{KPH}$ directors.

\subsection{Perceptions of $K P H$ duties and Functions}

Asked about the primary duties and functions of the $\mathrm{KPH}$, respondents cited as highest priorities: 1) forest management $(92.73 \%), 2)$ long-range planning $(87.27 \%), 3)$ forest inventory $(83.64 \%), 4)$ capacity building for KPH staff $(72.73 \%)$, 4) conflict resolution $(69.09 \%)$; and 5) forest protection and conservation (69.09\%) (see Figure 1). Other duties noted as important included enforcement, rehabilitation and reclamation, networking, community capacity building, administration and financial management, forest investment and business development, clarification of forest policies, forest utilization, and monitoring and evaluation. Many underscored the critical, cross cutting importance of staff capacity building and building good working relationships with local communities, including efforts at improving local economies. As one respondent commented: "We have to develop an approach to secure adequate incomes for people on the forest margins; if we can achieve this, Insya Allah, then we will have a much better chance of resolving forest management conflicts." 


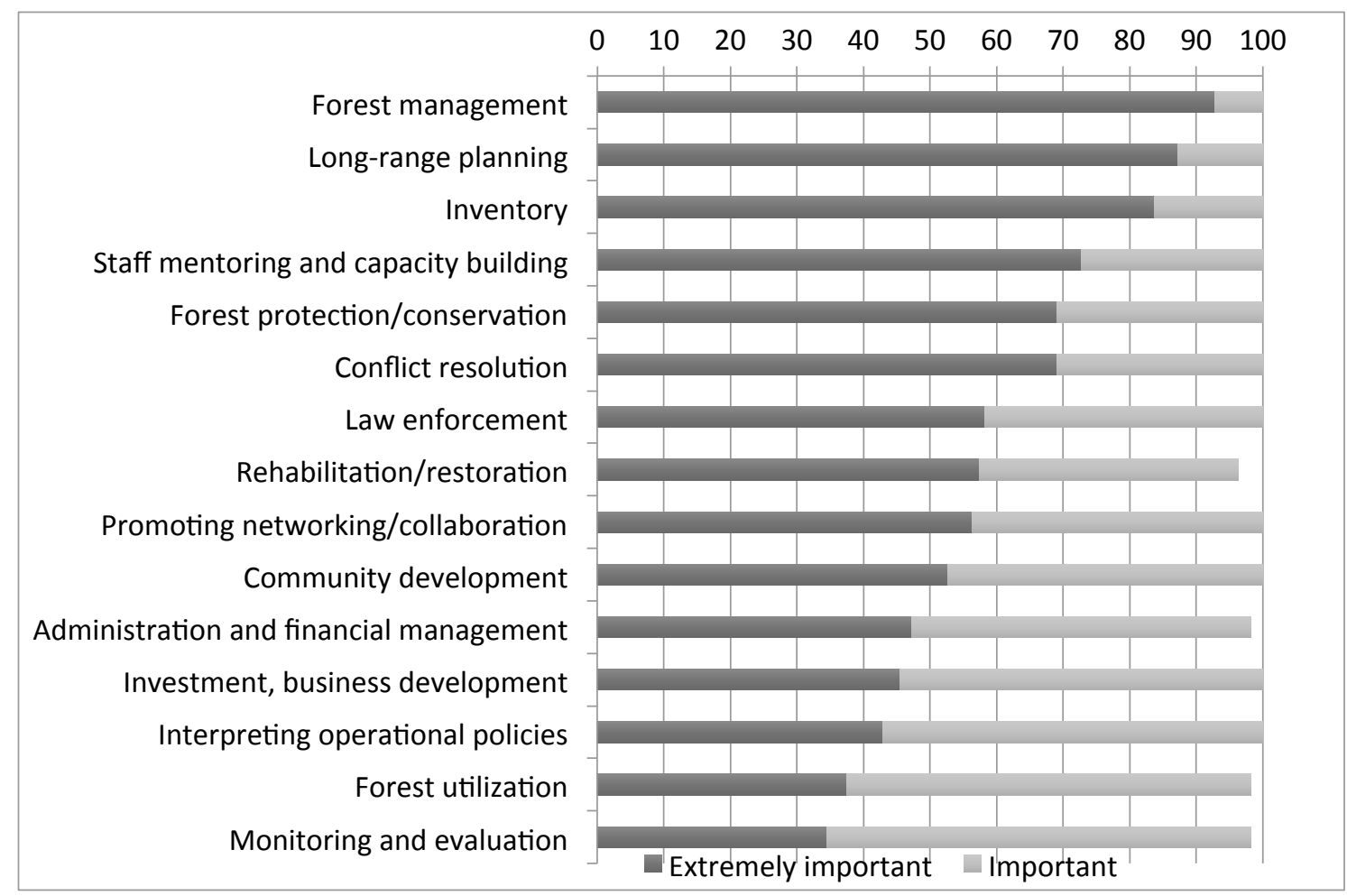

Figure 1. Primary duties/functions of KPH

\subsection{KPHs, conflict, and conflict management approaches}

The most common conflicts (extremely serious or serious) noted by respondents included forest encroachment (89.09\%), tenure disputes (86.79\%), boundary conflicts (84.91\%), illegal logging (75.48\%), and illegal land clearing (69.82\%). Also noted: customary claims, disputes over permitting, community-based conflicts (within and between communities, between local residents and migrants) and conflicts with concession holders (see Figure 2). This data underscores the extra-legal nature of the majority of forest management conflicts, and the challenges KPHs face as the front-line implementing unit for national forest policies. Several respondents noted this point in their comments, e.g., "Conflict resolution should be based on adhering to existing laws and policies; in the end, it all depends on political will and the commitment of all stakeholders to follow regulations." 


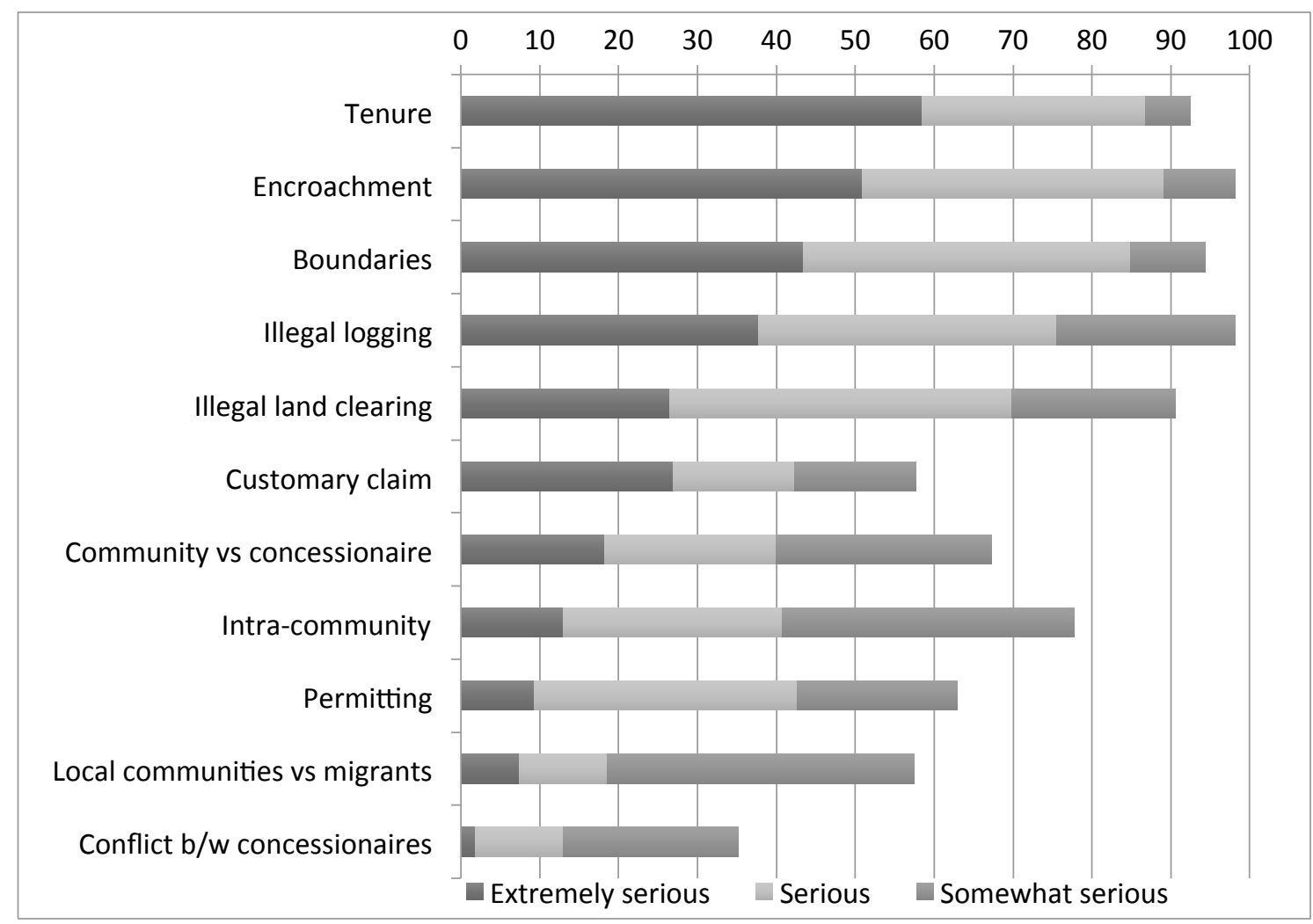

Figure 2. Type of conflict and level of seriousness

Commenting on the extent of conflict within the KPHs, almost half of respondents (48\%) estimated that active conflicts affected one quarter of the $\mathrm{KPH}$ area, $28 \%$ estimated conflicts impacted $26-50 \%$ of their $\mathrm{KPH}, 16 \%$ reported conflicts in $51-75 \%$ of the area, and $8 \%$ reported that $75-100 \%$ of their sites were affected by conflicts (Table 3 ). Conversely, only $25 \%$ of respondents reported their $\mathrm{KPHs}$ to be conflict free in more than half the total area. KPHs reporting that most of their area (75\% or more) is in current conflict, also noted that managing conflicts is a primary responsibility of the $\mathrm{KPH}$.

Table 3: KPH and area in conflict

\begin{tabular}{lrrrr}
\hline Extent of Conflict & $1-25 \%$ & $26-50 \%$ & $50-75 \%$ & $76-100 \%$ \\
\hline Currently in conflict & $48 \%$ & $28 \%$ & $16 \%$ & $8 \%$ \\
Potential Conflict & $24 \%$ & $47 \%$ & $16 \%$ & $14 \%$ \\
Conflict free & $48 \%$ & $27 \%$ & $17 \%$ & $8 \%$ \\
\hline
\end{tabular}

$\mathrm{KPH}$ directors voiced strong support for more constructive views about addressing forest management conflicts (Figure 3): $98.18 \%$ agreed with the statements that they needed to learn more about conflict and were willing to work with others to resolve disputes, $92.72 \%$ said that conflict resolution is an important part of their responsibilities, $89.09 \%$ said they were willing to seek assistance in resolving disputes, $87.27 \%$ said they seek compromise in addressing conflicts, $85.46 \%$ described themselves as capable facilitators or mediators, and $74.55 \%$ said they were effective negotiators. Among the representative comments: "Conflict resolution begins with an incremental approach to the communities, understanding their issues and concerns and the challenges they face, and mapping these out so that they are better understood and more readily addressed." Many other comments underscored the importance of building stronger working relationships among stakeholders, for example: "In addressing tenurial conflict in my area, we have 
formed an integrated team with local government, communities, and law enforcement, to negotiate through consensus building and seek alternative means of resolving the conflicts." These are important and encouraging statements, as it is widely recognized that acknowledging conflict, using effective communication, working collaboratively, and taking joint responsibility for solutions are keys to effective resolution (Moore, 1986).

At the same time, $65.46 \%$ agreed with the statement that conflicts must be resolved through extreme measures (e.g., through more direct involvement of law enforcement, stronger application of laws and policies), while $30.91 \%$ said they try to avoid conflicts as much as possible, $21.82 \%$ said that conflict is the primary responsibility of law enforcement agencies; only $5.46 \%$ said they preferred not to think about conflicts. These latter attitudes would be important to explore further in follow up research, as they are inconsistent with the $\mathrm{KPHs}^{\prime}$ legislative mandate, and may not serve as an effective strategy for resolving these disputes.

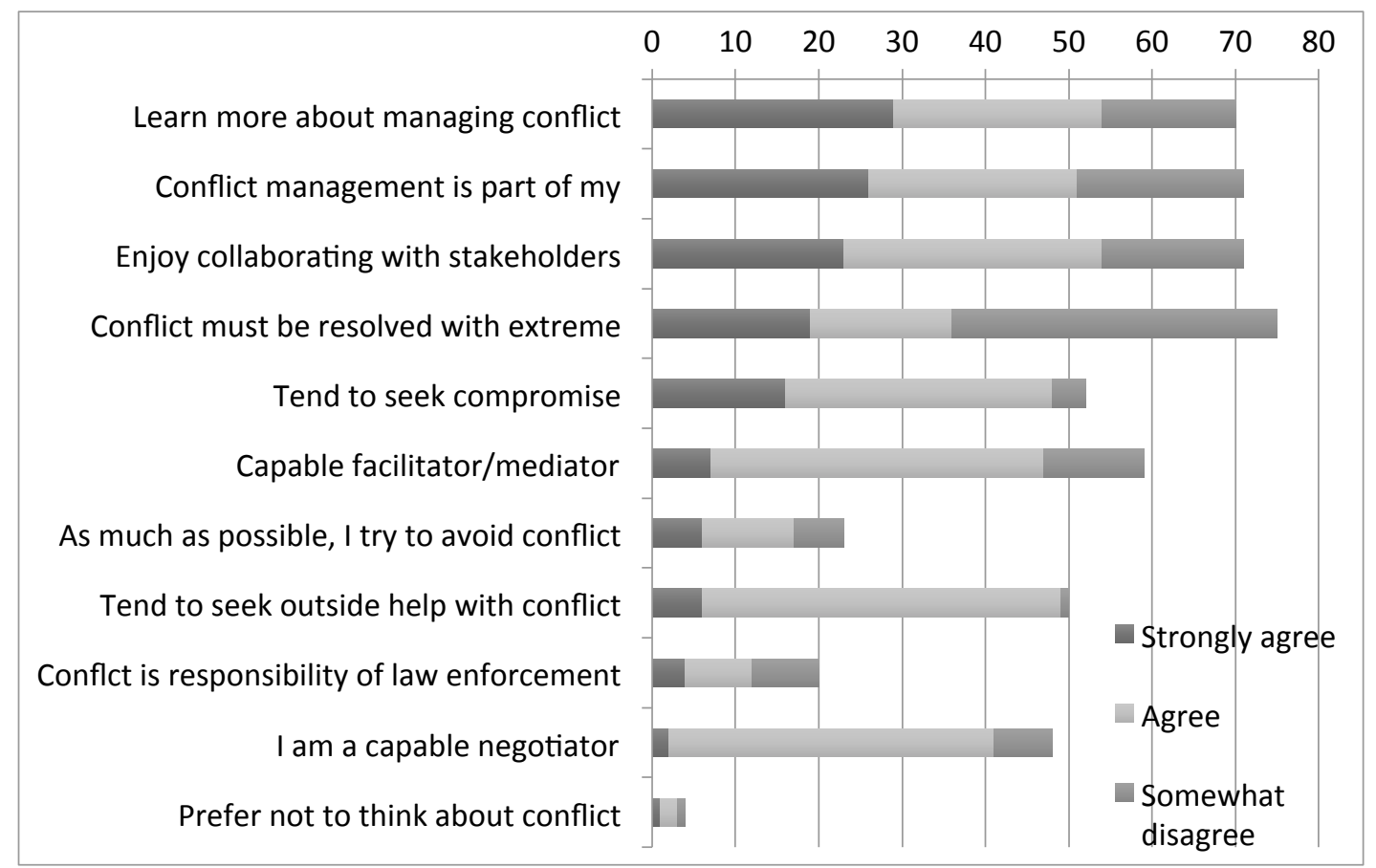

Figure 3. Attitudes about managing forest conflict

Asked about which actors have the greatest influence over forest management in their areas, respondents listed the Ministry of Environment and Forestry, KPHs, forest margin communities, and Regency-level governments, followed by provincial government, concession holders, and NGOs (see Figure 4). Many emphasized the MoEF's primary role in setting forest boundaries, establishing use classifications, and in setting overarching policies, and underscored the KPHs' role in implementing these policies and providing local level planning, management, and monitoring. Respondents also highlighted the important role of customary (adat) leaders in ensuring effective forest management. Many respondents underscored the need for synergy and coordination among actors, i.e., the importance of collaboration across jurisdictions, and among all actors, including government, communities, concession-holders, and NGOs. As one respondent commented: "The KPH is stuck in the middle, between government policies and practical realities; resolving conflicts requires the commitment of all government agencies, from national to local, and certainly the NGOs and forest margin communities share a common interest and mutual influence in achieving effective forest management."

Respondents identified the KPH and MoEF as the institutions having the greatest responsibility for resolving forest conflicts (both at $57.41 \%$ ), followed by District-level governments (44.44\%) and the Ministry of Agrarian Affairs and Spatial Planning (MAASP), which has authority for regulating and coordinating overall land use policies (39.22\%) (Figure 4). This is consistent with 
views expressed in other responses, that many of the disputes primarily relate to forest management and boundary issues, and that many of these disputes have national policy dimensions, but reflect local social and economic dynamics. However, respondents' comments acknowledged the multiple roles and responsibilities, and the complex interaction among stakeholders in addressing forest management conflict, for example, in this succinct summary of the role of various actors: "The three levels of government, National, Provincial and District governments, have the greatest influence on forest management, because they have responsibility for planning and administration of all forest lands. The Ministry, particularly, is the primary initiator of all these aspects of forest management and administration. The KPH, in contrast, is merely an implementer/operator of these management policies. Meanwhile, the NGOs serve a key role in extension and communication, as a bridge to the communities in helping convey improved understanding of our programs. Concession holders can exert both positive and negative influences - positive if they manage their site effectively, but negative if they simply obtain their permit but don't have the necessary management capability, which results in illegal activities like illegal logging, encroachment, occupation, etc. And obviously the community has the most immediate and direct relationship to the forest, so we have to continue to seek ways to improve their understanding and capacity, change their way of thinking about forest management toward greater social benefits and greater sustainability."

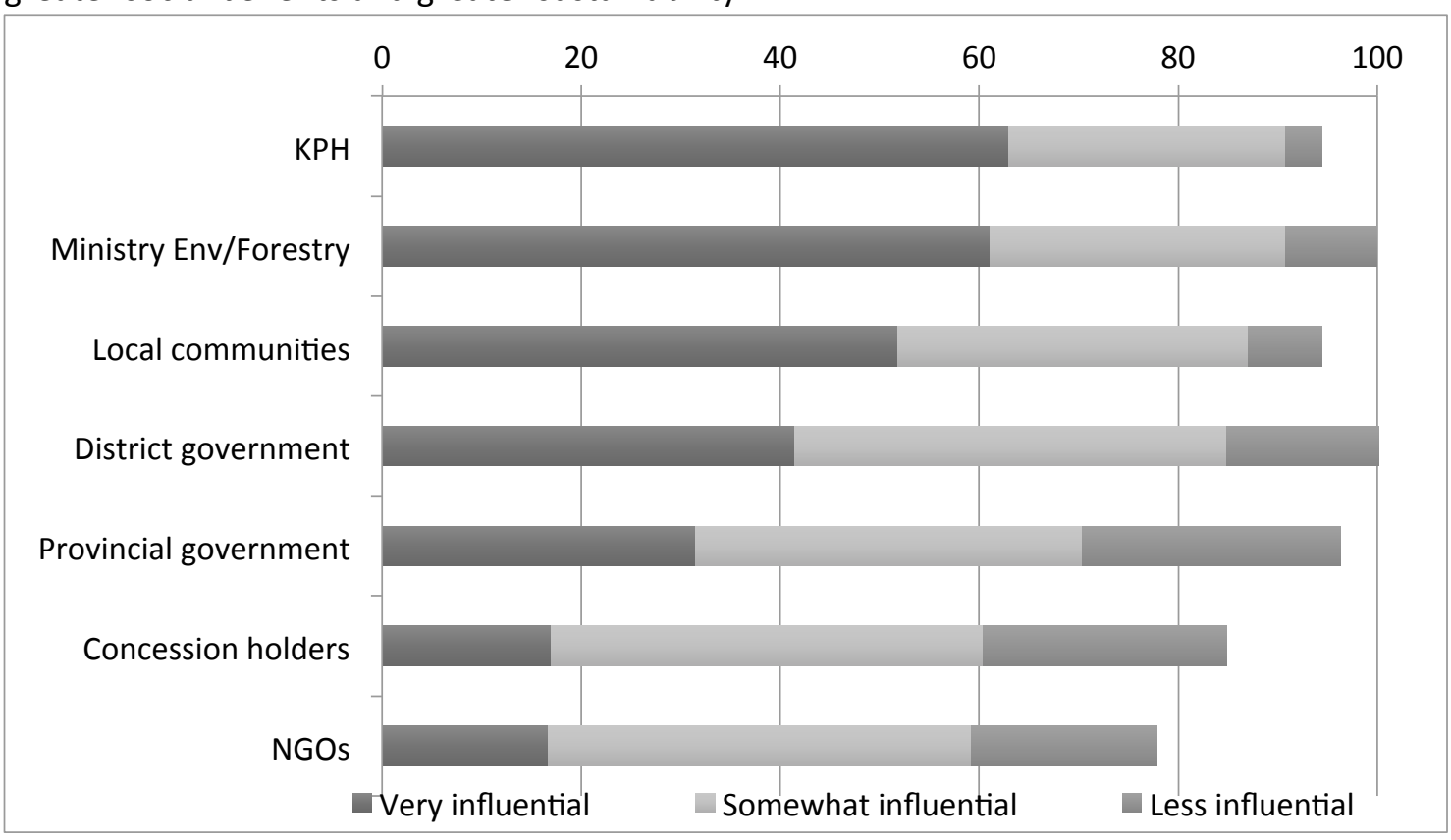

Figure 4. Actors and their influence over forest management

Commenting on the most effective approaches they have used to date in resolving conflicts, respondents generally rated pro-active measures as most effective: promoting collaboration among parties (92.31\%) developing partnership agreements ${ }^{2}$ (88.24\%), supporting staff training and capacity building (86.27\%), including conflict resolution plans within their long-term planning documents $(76.47 \%)$, collecting data $(71.16 \%)$, engaging a third-party neutral/mediator $(67.34 \%)$, and conflict mapping and analysis (67.31\%) (Figure 5). Least effective actions noted: using Free

\footnotetext{
2 Partnership agreements (kemitraan) are a relatively recent program initiative from the Minister of Forestry (Ministerial Regulation No P.39/2013) that augments existing community-based forestry initiatives such as village forests (hutan desa), social forestry (hutan kemasyarakatan, or HKM), and Partnership agreements allow for local discretion and more active participation of community groups in managing and sharing benefits of forest management (see Adnan et al. 2015).
} 
Prior and Informed Consent3 (FPIC) protocols (54.35\%), enhanced law enforcement (52.00\%), and development of grievance/complaint procedures (48.98\%). These results suggest a positive emphasis on more positive, pre-emptive approaches to mitigating conflicts through cooperation and staff skill building, but it is interesting to note the low scores for FPIC and the application of grievance procedures, both of which would be considered proactive, systems approaches to reducing conflict and its escalation. This may be a reflection of the more limited understanding and use of these two approaches, which are as yet uncommon within the KPH system.

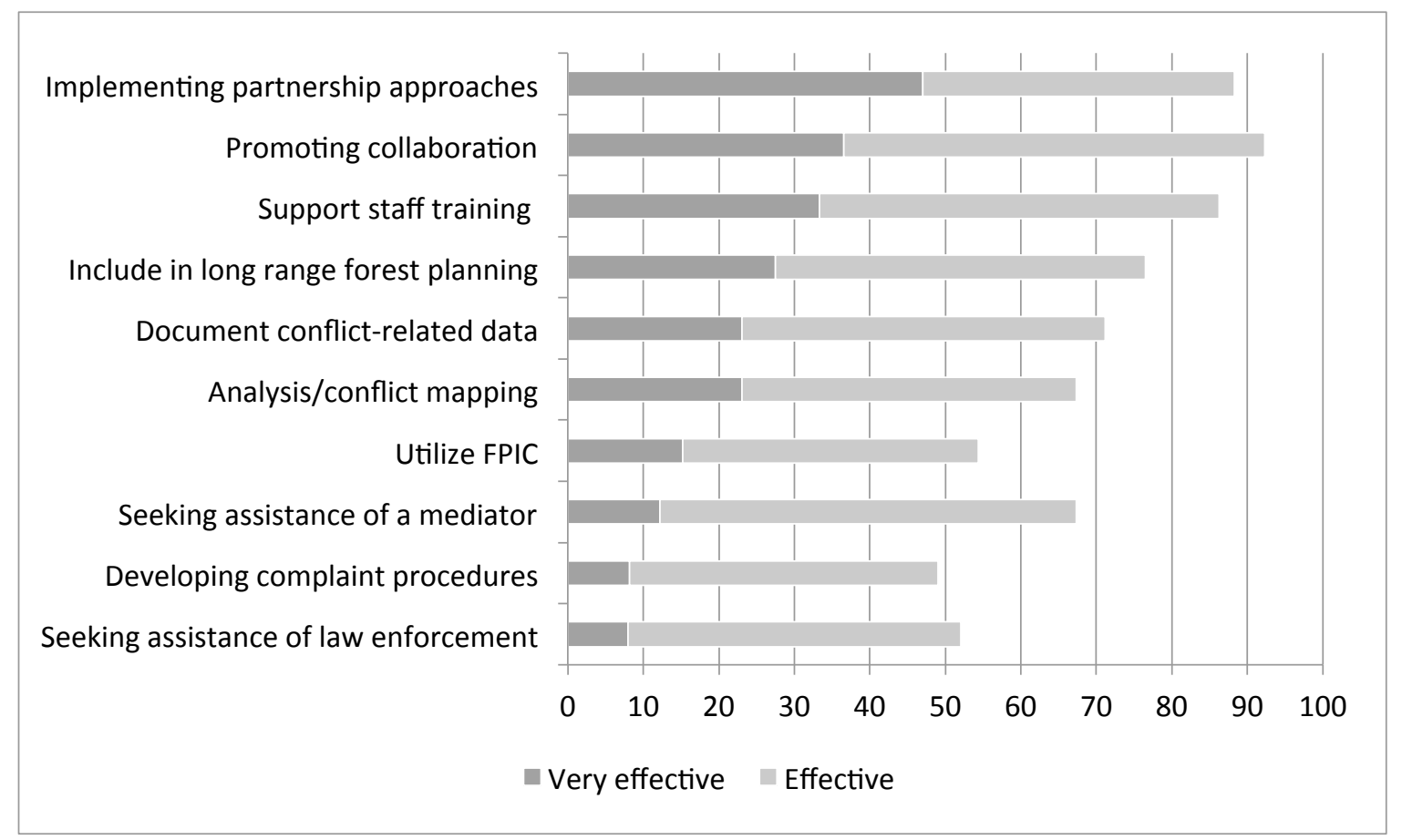

Figure 5. Most Effective Approaches for Managing Conflict

Asked about the support deemed most helpful to the KPH in resolving conflicts, respondents again emphasized more pro-active capacity building measures: partnership building (77.78\%), staff training $(74.07 \%)$, active engagement of community leaders $(74.07 \%)$, local adaptation of national policies (70.37\%), greater engagement of Regency government $(66.04 \%)$, increased budget for the $\mathrm{KPH}(62.96 \%)$, regular forest patrols (57.41\%), conflict mapping and documentation (55.56\%), and increased KPH staff numbers (48.15\%) (Figure 6). Worth noting here are the relatively low scores for greater engagement of law enforcement agencies (28.30\%) or the intervention of professional mediators (26.42\%), suggesting that many KPH directors feel they have the capacity, or could develop the capacity, for managing disputes.

\footnotetext{
${ }^{3}$ Free, Prior, and Informed Consent (FPIC) is the principle, outlined in the UN Declaration on the Rights of Indigenous Peoples, that a community has the right to give or withhold its consent to proposed projects that may affect the lands they customarily own, occupy or otherwise use Colchester, 2010). In Indonesia, FPIC is referred to by the acronym PADIATAPA (Persetujuan atas Dasar Informasi di Awal Tanpa Paksaan).
} 


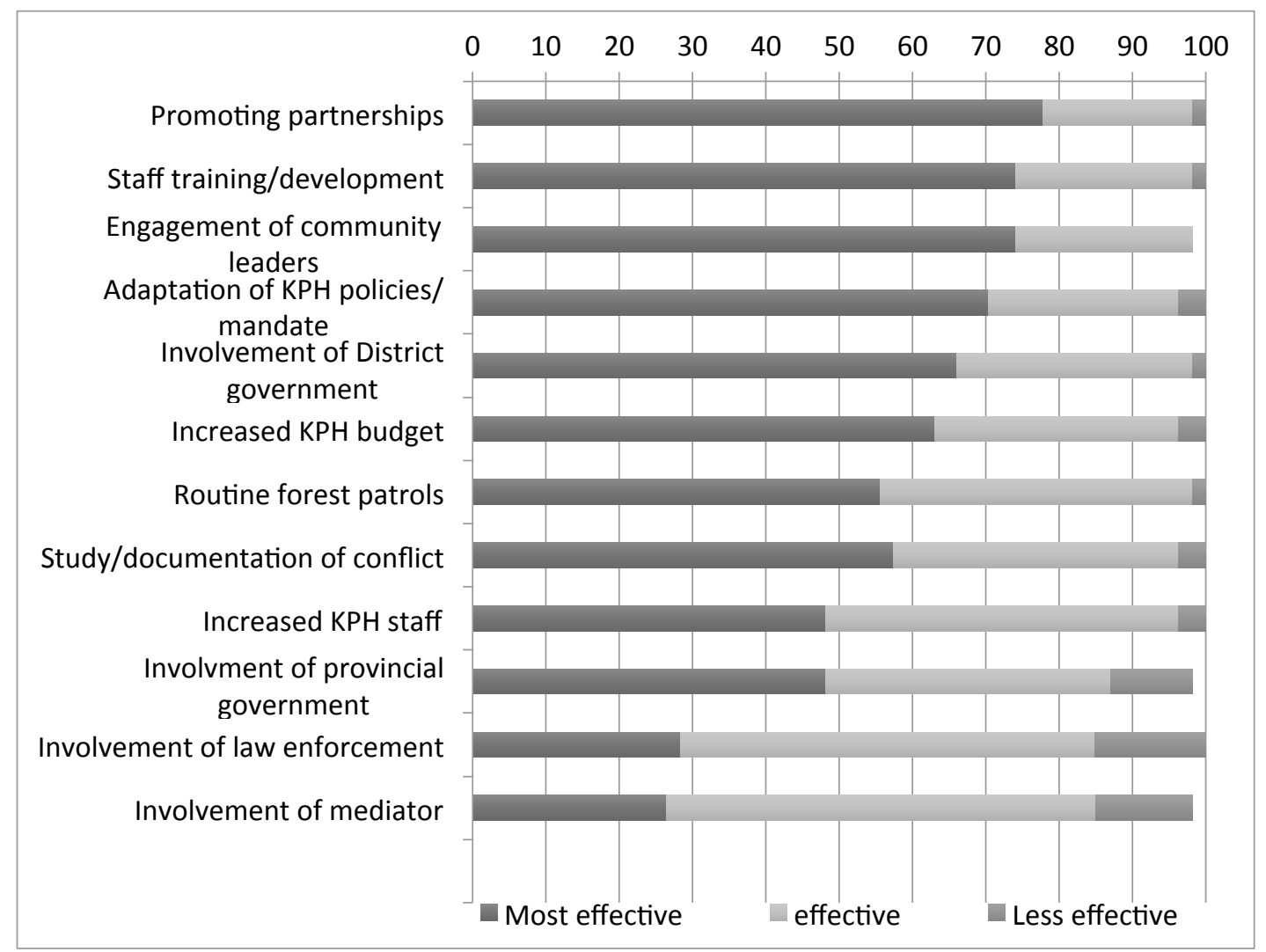

Figure 6. Support or interventions regarded as most helpful in resolving conflicts

\section{Discussion}

The results of this initial, broad-scale survey offer important insights into the current status of the KPHs, their leadership's perceptions of forest conflicts, and their sense of the KPHs' mandate, opportunities, and needs in addressing forest management disputes. The response rate $(69.6 \%)$ and the many thoughtful and insightful comments received within the survey, suggest a high level of interest in the topic, and, as one respondent suggested, the sense that "KPHs will never be free of conflict with local communities, so we will have to continue seeking ways to manage conflict effectively."

The profile of KPHs and conflict that emerges from the survey underscores the following key points:

- The KPHs are still in a very early stage of development, and are struggling with a complex and rapidly evolving policy and institutional framework, one in which, as many respondents noted, the KPHs are "stuck in the middle", and in the position of "implementer/operator of...management policies". Overall, they are constrained by limited professional staff, and with leadership and staff who lack on-the-job experience. Note that less than $4 \%$ of KPH leaders have been in their positions for more than 5 years; fewer than half of the KPHs have more than 20 permanent staff, and many rely heavily on contract labor. In terms of basic skills, only a little more than half $(55 \%)$ have participated in any training related to conflict management, and this only at the very introductory level.

- KPH leadership's sense of priorities very much focuses on the fundamental aspects of forest management: inventory, planning, forest protection, conservation, and restoration. However, staff development, conflict resolution, routine law enforcement, networking and collaboration, and socializing national forest policies, followed closely in terms of perceived priorities and responsibilities.

- Forest management conflicts are primarily attributed to encroachment, illegal logging and land clearing, and tenure and boundary disputes, reflecting a combination of both limited management capacity, as well as an emboldened sense of peasant empowerment (Maryudi et 
al., 2016). But respondents also noted that customary claims, permitting/licensing, and intraand inter-community conflicts constituted frequent causes of forest management disputes, and this again suggests the need for greater clarity of national policies and more consistent implementation at the local level.

- KPH leaders generally offered support for more constructive comments about dealing with conflict: an acknowledgement of the need to learn more about approaches to conflict management, a willingness to work with others to resolve disputes, the recognition that dealing with conflict is an important part of their responsibilities, and their openness to seeking compromise. In short, they tend to embrace their role and responsibility in managing conflict, and the majority of respondents described themselves as capable facilitators, mediators, or negotiators.

- Respondents underscored the importance of more collaborative approaches for addressing conflict: partnership and network building, staff development, engaging community leaders and other key partners, adaptation of policies to accommodate local context and needs. Considered as lesser importance were more coercive means, such as increasing law enforcement and forest patrols, and seeking the outside assistance of professional mediators.

Overall, these results juxtapose a generally constructive view by KPH leadership over their role and responsibility in addressing forest management conflicts, with an extremely challenging social, institutional, and political setting - multiple actors and issues, changing policies and authority, and uncertainty in their role and degree of autonomy (Sahide et al., 2015). The KPHs' willingness to embrace their responsibility and acknowledge the need for enhanced staff capacity, greater flexibility in adapting policy, and financial and analytical support, offers a necessary, but certainly insufficient, foundation for positive change. However, while these survey results are helpful in articulating the perspectives of the KPH leaders, they must be tempered with an understanding of the limits of self-assessment, and they are necessarily constrained by the harsh realities of a forest governance system in need of significant reform (Contreras-Hermosilla and Fay, 2005; World Bank, 2014). Certainly additional research could offer deeper understanding of the challenges faced by $\mathrm{KPHs}$ in addressing the changing policy framework (e.g., the ongoing shift from national to regional control, balancing economic and environmental priorities), the social and economic context (e.g., by region, by forest type), the relationship with local communities and other key actors, and the capacity of individual KPHs and their staffs.

In their review of 118 conflict cases, Yasmi et al. (2006) underscored the fact that natural resource management conflicts necessarily involve multiple stakeholders and complex, interdependent issues and interests. Many of these site-based disputes are situated within, and informed by more macro-level governance structures (Wulan et al., 2004; Sahide and Giessen, 2015). It is significant, therefore, that KPH leaders report that tenure and boundary disputes, and a range of illegal activities (encroachment, land clearing, and illegal logging), constitute the majority of forest management disputes in Indonesia. While the KPHs represent the potential for decentralizing and improving forest governance, the system still requires stronger integration within provincial and district-level governments (Kartodihardjo et al., 2011; Bae et al., 2014), greater authority for KPHs to settle disputes over community access rights, and clearer guidance for KPHs in monitoring and supervising concession operations (Ota, 2015). There remain real sources of tension for the KPHs (with their implicit emphasis on community-based forestry approaches) in positioning themselves within these national, provincial and district level bureaucracies (Sahide et al., 2016a,b).

The collaborative, stakeholder-based approaches emphasized in many of the survey responses do offer promise, and underscore a commitment to a more socially and environmentally appropriate means of increasing local participation in forest management decision making. Embracing collaborative processes can be a truly liberating and empowering process for communities and other stakeholders, but the experience with co-management regimes in many places suggests that such arrangements can result in the cooptation or further marginalization of local interests (Castro and Neilsen, 2001). Indeed, while the merits of community forest approaches (such as partnership agreements) lie, potentially, in the simplification of permit 
issuance procedures and reduced transaction costs, national legislative reform is still needed to expand both the area of potentially usable forest for local communities, as well as the KPHs' authority to include non-concession areas (Jang and Bae, 2014).

While skill building, partnership development, and collaboration with stakeholders are all important elements of improved governance, the plethora of boundary disputes and illegal activities still requires significant legal reform and enhanced law enforcement methods. The KPHs represent an important element of this reform, and further research on individual KPHs' capacity can provide insights for KPHs to share their early successes and experiences with project implementation, including lessons learned in engaging local communities and indigenous groups. Similarly, understanding individual $\mathrm{KPHs}^{\prime}$ ability to analyze conflicts and distinguish causality, including socio-economic and environmental aspects, as well as location and context-specific dynamics, would be an important contribution for improving management of these conflicts (Gritten and Mola-Yudego, 2011).

Dhiaulhaq et al. (2015) have emphasized that successful mediators take on a variety of roles. They facilitate communication among parties and help explore, and when necessary propose, alternative solutions. They often require the technical capacity and negotiation skills of the parties involved to address imbalances, as well as providing resources and technical assistance. Theoretically, at least, the KPHs have the mandate, and in some cases the experience and skill, to play this important role. Survey results have emphasized KPH directors' general confidence in their ability to serve this function. However, while mediation can certainly be an effective tool for resolving forest management disputes (FAO, 2000; Dhiaulhaq et al., 2015), it remains questionable whether the KPH - as an institution, since it is an active stakeholder in many of these conflicts can serve as an effective, neutral mediator (Persch-Orth and Mwangi, 2016).

More importantly, the nature and extent of conflicts described by KPHs are clearly more chronic in nature, and require broader systemic change, rather than site-based mediation - to resolve existing conflicts, and prevent future conflicts from occurring. In the absence of this broad-scale systemic change, the central question for the KPHs, if they are to be considered as effective intermediaries, is the degree of discretion and authority they are given for promoting effective, collaborative solutions that are suitable to local conditions.

\section{Conclusions}

The KPHs continue to be viewed as a fundamental element of forest governance reform in Indonesia. A projected $600 \mathrm{KPHs}$ is expected to be fully functional by 2020 , and they are increasingly being viewed as the frontline presence for the Ministry of Environment and Forestry in managing the forest estate in Indonesia (Kartodihardjo et al., 2011; Hernowo and Ekawati, 2014). However, as Ota (2015) has noted, a mere increase in numbers is an unlikely solution to the fundamental challenges represented by the complex forest management conflicts described above. For the KPHs to function effectively at the operational level, clear legal and policy mechanisms, reconciliation of jurisdictional roles and responsibilities, and enhanced enforcement, are needed to support improved implementation in forest management.

The KPHs can certainly play an important role as local intermediaries, and in some cases, as mediators to local conflicts, but only with a more concerted effort from central, provincial, and district-level government authorities to provide greater consistency in policies and regulations, improved policy communication, and a sustained commitment to strengthening the capacity of individual KPHs (Kim et al., 2015).

As one respondent commented in a final summary response: "to be successful, [KPHs] will have to address three fundamental issues: building staff capacity (in terms of both quality and quantity), securing adequate budgets that provide for independence, and appropriate regulations that truly acknowledge and seek to accommodate a multi-stakeholder perspective." 


\section{Appendix A: Survey of KPHs and Conflict in Indonesia [English translation from the original] INTRODUCTION}

This survey is designed to gain information about your knowledge, attitudes, and practices in dealing with conflict. The survey is a collaborative effort of the National Association of KPHs, the University of Mataram, University of Arizona, and Northern Arizona University. Survey results will be analyzed and presented in a national workshop (November, 2015), for consideration in plans for future KPH training and capacity building efforts, and we are also hoping to publish the results in academic publications.

Thanks for your willingness to take time to fill in the questionnaire. We hope you will complete the questions honestly, based on your own experience and perspective. Your responses will be confidential (anonymous), and will not be attributed to you as an individual.

If you have any questions or comments about the survey, please contact:

Ir. Madani Makarom, M.Si

Director, KPH Rinjani Barat

Coordinator, National Association of KPHs in Indonesia

aganampuh@gmail.com

Dr. Sitti Latifah

Forestry Studies Program

University of Mataram

slatifa23@yahoo.com

\section{BASIC INFORMATION}

1) KPH location:
a. Sumatera
b. Jawa
c. Bali-Nusa Tenggara
d. Kalimantan
e. Sulawesi
f. Maluku

2) $\mathrm{KPH}$ organizational status:
a. Still in process
b. Technical Operation Unit (UPTD) based on a decree by the Bupati or Governor
c. Technical Operation Unit (UPTD) at the regional government level
d. Local government working unit (SKPD) at the regional government level
e. Technical Operation Unit (UPTD) - financial management within local government service agency (PPK BLUD)
f. Local government working unit (SKPD) - financial management within local government service agency (PPK BLUD)

3) Total area of the KPH:
a. Less than 50,000 ha
b. 50,000 to $<100,000$ ha
c. 100,000 to $<150,000$
d. 150,000 to $<250,000$
e. $>250,000$

4) Total number of staff working in the $\mathrm{KPH}$ :
a. Civil servants
b. Contracted staff
c. Local project level staff

(Choices: $(1-5,6-10,11-20,21-50,51-100,>100)$

5) How many years have you worked for the KPH? 

a. Less than 1 year
b. 1-2 years
c. 3-5 years
d. More than 5 years

6) Your current age:
a. $20-25$
b. $26-30$
c. $31-35$
d. $36-40$
e. $41-45$
f. $46-50$
g. $51-55$
h. $56-60$
i. More than 60

7) Educational attainment:
a. High school/Technical High School
b. Diploma
c. Bachelor's degree
d. Master's degree
e. Doctorate degree
f. Other (please specify)

8) Field or program of study:
a. Biology
b. Geography
c. Social sciences
d. Economics/business
e. Law
f. Agriculture
g. Forestry
h. Technical/engineering
i. Math/physics
j. Other

9) Have you ever attended a class or training course related to conflict management?
a. Yes
b. No

If yes, please specify the title of the class

\section{INFORMATION ON KPH AND CONFLICT}

10) Please rank the following KPH tasks and functions in order of perceived priority:
a. Forest management
b. Forest inventory
c. Preparation of forest management plans
d. Forest rehabilitation and restoration
e. Forest protection and conservation
f. Implementation of forest policies
g. Staff development - mentoring and capacity building
h. Network building with stakeholders
i. Law enforcement
j. Monitoring and evaluation of forest management
k. Investment and business development
I. Support to local communities
m. Conflict management
n. Administration and financial management
o. Other 
11) Please indicate the types of conflicts, and their level of seriousness, that you are experiencing in the $\mathrm{KPH}$ :
a. Boundary conflicts
b. Land tenure conflicts
c. Illegal logging
d. Encroachment (illegal farming)
e. Conflicts related to permits/licenses
f. Local community conflicts
g. Conflicts between local communities and immigrants/outsiders
h. Conflicts between concession-holders and communities
i. Conflicts between concession-holders
j. Claims of indigenous communities
k. Others

(Choices: Very serious, somewhat serious, moderate, low, not serious)

12) In your opinion, what percentage of the $\mathrm{KPH}$ area is currently or potentially in conflict?
a. Currently in conflict
b. Potentially in conflict
c. Conflict free

(Choices: 1 - 25\%, $26-50 \%, 51-75 \%, 75-100 \%$ )

13) How would you describe your attitude about facing and/or managing conflict?
a. I try not to think about conflict
b. As far as possible, I avoid dealing with conflict
c. Conflict must be resolved with extreme measures
d. Conflict resolution is the responsibility of law enforcement agencies
e. Conflict resolution is part of my job responsibility
f. I am capable of resolving conflicts with other stakeholders
g. I tend to seek help from competent professionals in resolving conflicts
h. I would like to gain more training in conflict resolution
i. I am a capable facilitator/mediator
j. I look for compromise in resolving conflicts
k. I like working with others to resolve conflicts

(Choices: Strongly agree, somewhat agree, neutral, somewhat disagree, strongly disagree)

14) Please indicate the degree of influence of different agencies/actors in forest management in your $\mathrm{KPH}$ ?
a. Ministry of Environment and Forestry
b. Provincial government
c. Regency government
d. $\mathrm{KPH}$
e. NGOs
f. Concession-holders
g. Local communities
h. Other

(Choices: Extremely influential, somewhat influential, neutral, limited influence, no influence)

15) What is your $\mathrm{KPH}$ doing to resolve conflicts in your area?
a. Conducting conflict analysis/mapping
b. Gathering data related to conflict
c. Including conflict management in long term management plans
d. Supporting staff training
e. Promoting collaboration among stakeholders
f. Implementing Free, Prior, and Informed Consent (FPIC)
g. Developing complaints procedures
h. Implementing partnership approaches
i. Seeking assistance of outside mediators
j. Seeking assistance of law enforcement
k. Haven't done anything 
(Choices: Very effective, somewhat effective, neutral, low effectiveness, not at all effective)

16) In your opinion, who is most responsible for resolving conflicts in your $\mathrm{KPH}$ ?
a. Ministry of Environment and Forestry
b. Ministry of Agrarian Affairs and Spatial Planning
c. Ministry of Energy and Mineral Resources
d. Ministry of Home Affairs
e. Provincial government
f. Regency government
g. Law enforcement (police, courts)
h. $\mathrm{KPH}$
i. NGOs
j. Relevant private sector companies
k. Outside mediators
I. Other

(Choices: Most responsible, somewhat responsible, neutral, less responsible, not responsible)

17) In your opinion, what assistance or support is needed to resolve conflicts in your area?
a. Additional KPH staff
b. Training for current KPH staff
c. Analysis and documentation of conflicts
d. Adjustment of policies and the mandate of the $\mathrm{KPH}$
e. Promoting partnership approaches
f. Involvement of law enforcement
g. Involvement of Regency government
h. Involvement of Provincial government
i. Involvement of local leaders (community, religious, cultural)
j. Regular forest patrols
k. Involvement of outside mediators
I. Increased $\mathrm{KPH}$ budget
m. Other

(Choices: Very necessary, somewhat necessary, not very necessary, not at all necessary)

18) What do you most hope for in resolving conflicts in your area?
n. Enhanced performance and reputation of the KPH
o. Improved working relationships with local communities
p. Improved working relationships among all stakeholders
q. Increased community support for KPH programs
r. Reduced costs and losses from conflicts
s. Improved security
t. Increased income for local communities
u. Community empowerment
v. Increased understanding and attention for the environment
w. Improved forest health conditions
x. Other

(Choices: Most important, somewhat important, less important, not important)

19) Any other comments you'd care to share with us to expand on your answers above?

\section{Acknowledgments}

This research was supported by a Global Innovation Initiative grant from the United States Department of State and the Office of Foreign Affairs, United Kingdom. Additional support was provided by the Ford Foundation and the Climate and Land Use Alliance. We benefited greatly from early input received from several members of the National Association of Forest Management Units in Indonesia. We especially thank KPH directors for taking the time to complete the survey questionnaire and provide comments on preliminary findings 


\section{References}

Adnan, H., H. Berliani, G. Hardiyanto, Suwito, and D. K. Sakti. (2015). Pemberdayaan Masyarakat melalui Kemitraan Kehutanan. The Partnership for Governance Reform, Jakarta.

Ayling, R.D., and K. Kelly. (1997). Dealing with conflict: natural resources and dispute resolution. Commonwealth Forest Review, 76 (3): 182-185.

Bae, J.S., Y.S. Kim, L.A. Fisher, M. Moeliono, and J. DeShazo. (2014). Promises and Perils of Decentralized Forest Governance: The Case of Indonesia's Forest Management Units in Reducing Emission from Deforestation and Forest Degradation (REDD+). Society and Natural Resources, 27:1346-1354

Bannon, I., and P. Collier. (2003). Natural Resources and Violent Conflict. World Bank, Washington DC.

Brockhaus, M., K. Obidzinski, A. Dermawan, Y. Laumonier, and C. Luttrell. (2012). An overview of forest and land allocation policies in Indonesia: Is the current framework sufficient to meet the needs of REDD+?. Forest Policy and Economics, 18:30-37.

Castro, A.P., and E. Nielsen. (2001). Indigenous people and co-management: implications for conflict management. Environmental Science and Policy, 4: 229-239.

Colchester, M. (2010). Free, Prior and Informed Consent: Making FPIC work for forests and peoples. The Forest Dialogue Research Paper No. 11, Yale University, New Haven.

Collier, P., and A. Hoeffler. (2002). Greed and Grievance in Civil War. Oxford economic papers, 56(4): 563-595.

Contreras-Hermosilla, A., and C. Fay. (2005). Strengthening Forest Management in Indonesia Through Land Tenure Reform: Issues and Framework for Action. World Agroforestry Center, Bogor, Indonesia.

Davis, R., and D. M. Franks. (2014). Costs of Company-Community Conflict in the Extractive Sector. Corporate Social Responsibility Initiative Report No. 66. Harvard Kennedy School, Cambridge, MA.

De Koning, R., D. Capistrano, Y. Yasmi, and P. Cerutti. (2008). Forest-Related Conflict: Impacts, Links and Measures to Mitigate. Rights and Resources Initiative, Washington, D.C., USA.

Deloges, C., and M. Gauthier. (1997). Community forestry and forest resource conflicts: an overview. Paper prepared for the XI World Forestry Congress, Antalya, Turkey.

Dhiaulhaq, A., D. Gritten, T. De Bruyn, Y. Yasmi, A. Zazali, and M. Silalahi. (2014). Transforming conflict in plantations through mediation: Lessons and experiences from Sumatera, Indonesia. Forest Policy and Economics, 41 (0):22-30.

Dhiaulhaq, A., T. De Bruyn, and D. Gritten. (2015). The use and effectiveness of mediation in forest and land conflict transformation in Southeast Asia: Case studies from Cambodia, Indonesia and Thailand. Environmental Science and Policy, 45 (0):132-145.

Food and Agriculture Organization (FAO). (2000). Conflict and Natural Resource Management. FAO, Rome.

Forest Watch Indonesia. (2011). Keadaan Hutan Indonesia. Forest Watch Indonesia, Bogor Indonesia.

Gritten, D., and B. Mola-Yudego. (2011). Exploration of the relevance of geographical, environmental and socio-economic indicators regarding forest conflict types. International Forestry Review, 13 (1): $46-55$.

Hansen, M. C., P. V. Potapov, R. Moore, M. Hancher, S. A. Turubanova, A. Tyukavina, D. Thau, S. V. Stehman, S. J. Goetz, T. R. Loveland, A. Kommareddy, A. Egorov, L. Chini, C. O. Justice, and J. R. G. Townshend. (2013). High-Resolution Global Maps of 21st-Century Forest Cover Change. Science 342 (6160), 850-853

Harwell, E. (2011). Forests in Fragile and Conflict-Affected States. World Bank, Washington, D.C.

Hernowo, B., and S. Ekawati (eds.). (2014). Operasionalisasi Kesatuan Pengelolaan Hutan (KPH): Langkah Awal Menuju Kemandirian. Kanisius, Jakarta.

Hellstrom, E. (2001). Conflict cultures: Qualitative comparative analysis of environmental conflicts in forestry. Silva Fennica Monographs 2. 
Institute for the Policy Analysis of Conflict (IPAC). (2014). Indigenous Rights vs. Agrarian Reform in Indonesia: A Case Study from Jambi. IPAC, Jakarta. Retrieved from http://file.understandingconflict.org/file/2014/04/IPAC_Report_9_Case_Study_from_Jambi _web.pdf in February 102016

Jang, S.K., and J.S. Bae. (2014). New Forest Governance in Indonesia: A Forest Partnership between Forest Management Units and Local Communities. Southeast Asia Study 24 (4): 95-144

Kartodihardjo, H., Nugroho, B., Putro, H.R. (2011). Forest Management Unit Development (FMU): Concept, Legislation and Implementation. Ministry of Forestry, FORCLIME Forest and Climate Change Programme, Jakarta, Indonesia.

Kim, Y.S., J.S. Bae, L. A. Fisher, S. Latifah, M. Afifi, S.M. Lee, and I.A. Kim. (2015). Indonesia's Forest Management Units: Effective intermediaries in REDD+ implementation?. Forest Policy and Economics, 62:69-77.

Krott, K., A. Bader, C. Schusser, R. Devkota, A. Maryudi, L. Giessen, H. Aurenhammer. (2014). Actor-centered power: The driving force in decentralised community based forest governance. Forest Policy and Economics, 49: 34-42.

Lee, K. (1997). Compass and Gyroscope: Integrating Science and Politics for the Environment, Island Press, Covelo, California.

Maryudi, A., Citraningtyas, E. R., Purwanto, R. H., Sadono, R., Suryanto, P., Riyanto, S., \& Siswoko, B. D. (2016). The emerging power of peasant farmers in the tenurial conflicts over the uses of state forestland in Central Java, Indonesia. Forest Policy and Economics, 67, 70-75.

Ministry of Forestry (MoF). (2014). Executive Summary About Forest Management Units (February 2014). Ministry of Forestry, Jakarta, Indonesia.

Moore, C. W. (1986). The Mediation Process: Practical Strategies for Resolving Conflict. Jossey-Bass, San Francisco.

Ota, M. (2015). Can Forest Management Units improve the management of state forests in Indonesia's outer islands? Institutional analysis and case studies from Lampung province of Sumatra. International Forestry Review, 17(1), 76-85.

Persch-Orth, M., and E. Mwangi. (2016). Company-community conflict in Indonesia's industrial plantation sector, CIFOR info brief, No. 143, May 2016

Republic of Indonesia (ROI). (2007). Government Regulation No. 6/2007 Forest Arrangement and Establishment of Forest Management Plan as well as Forest Exploitation (in Bahasa Indonesia). Republic of Indonesia, Jakarta, Indonesia.

Sahide, M.A.K., and L. Giessen. (2015). The fragmented land use administration in Indonesia: Analysing bureaucratic responsibilities influencing tropical rainforest transformation systems. Land Use Policy, 43: 96-110.

Sahide, M. A. K., Maryudi, A., Supratman, S., \& Giessen, L. (2016a). Is Indonesia utilising its international partners? The driving forces behind Forest Management Units. Forest Policy and Economics, 69, 11-20.

Sahide, M.A.K., S. Supratman, A. Maryudi, Y.S. Kim, and L. Giessen. (2016b). Decentralisation policy as recentralisation strategy: forest management units and community forestry in Indonesia, International Forestry Review, 18 (1): 78 - 95

World Bank. (2014). Towards Indonesian Land Reforms: Challenges and Opportunities. A Review of the Land Sector (Forest and Non-forest) in Indonesia, World Bank, Jakarta.

Wulan, Y.C., Y. Yasmi, C. Purba, and E. Wollenberg. (2004). Analisa Konflik Sektor Kehutanan di Indonesia 1997-2003. Center for International Forestry Research, Bogor.

Yasmi, Y. (2003). Understanding conflict in the co-management of forests: The case of Bulungan Research Forest. International Forestry Review, 5(1): 38-44.

Yasmi, Y., H. Schanz, and A. Salim. (2006). Manifestation of conflict escalation in natural resource management. Environmental Science and Policy, 9:538-546.

Yasmi, Y., L. Kelley, D. Murdiyarso, and T. Patel. (2012). The struggle over Asia's forests: an overview of forest conflict and potential implications for REDD+, International Forestry Review, 14(1): 2012 